\title{
THE ENERGY POVERTY SEVERITY INSPECTED IN ZDAR NAD SAZAVOU
}

\author{
Michal Bacovsky ${ }^{1}$ \\ ${ }^{1}$ Czech Technical University in Prague, Faculty of Civil Engineering, Thakurova 7, Prague 6, Czech \\ Republic, michal.bacovsky@fsv.cvut.cz
}

\begin{abstract}
The article focused on energy poverty and its prevention among 258 clients of the Home Social Care Service in the town Zdar nad Sazavou in the Czech Republic. The old and dependent people who need daily assistance are the typical vulnerable group. The root causes of clients' vulnerability were studied. The research showed specific problems with data gaining in case of dependent people. The most significant factor for the ability to prevent or to reduce the energy poverty was found the client's age. The older person the more limits to avoid or to prevent the energy poverty. The second important factor was the contact with the family. The most appropriate tool to prevent energy poverty was found the information campaign tailored to old people and reflecting their specific needs and limits.
\end{abstract}

\section{Keywords}

Energy efficiency; energy management; energy poverty

\section{JEL Classification}

132 Measurement and Analysis of Poverty

R21 Housing Demand

DOI: $\underline{\text { https://doi.org/10.14311/bit.2019.02.05 }}$

Editorial information: journal Business \& IT, ISSN 2570-7434, CreativeCommons license (c) (1) published by CTU in Prague, 2019, http://bit.fsv.cvut.cz/ 


\section{Introduction}

The energy poverty (EP) was primarily observed in the United Kingdom in early $80^{\prime}$ as the result of the oil crisis. The EP appeared by the people who could not afford to keep their homes adequately warm. The consequences of cold home are mostly health diseases, reduced social status and generally decreased quality of life. The medical care and other connected costs are higher than an aid offered to the EP tackling. The EP issue was later investigated in the other European countries too. The each country developed its own EP definition concerning the local conditions and citizens' manners. The variability of national definitions complicates the international comparing.

There are two basic approaches how to define the EP. The first approach is based on the recommended temperature in the rooms of the dwelling given by the World Health Organization or by the official experts in each country. The weak point of this approach is the variability of individual demands on the room temperature required for wellbeing.

The second approach focuses on the household's expenditures for the energy and it's relatively portion of the household total income. The energy expenditures should not exceed the arbitrary given portion (usually $10 \%$ ) which authors consider to be adequate. The problem is arbitrary given value which does not reflect real EP in case the rest of total household's income is high enough to ensure very comfortable living style.

The European Energy Network defines the EP as "individuals or households are not able to adequately heat or provide other required energy services in their homes at affordable cost" [11]. The very common definition says "EP occurs if the household expenditures for adequate heating are higher than $10 \%$ of total income"[13]. The review of different EM definitions in various world regions including US resulted into complex EP definition as: "an inability to realize essential capabilities as a direct or indirect result of insufficient access to affordable, reliable and safe energy services, and taking into account available reasonable alternative means of realizing these capabilities" [6].

The Scottish Government defines "EP occurs in case the energy expenditures necessary for acceptable warmth exceeds $10 \%$ of total income. The acceptable warmth is defined as $21^{\circ} \mathrm{C}$ for the living room and $18^{\circ} \mathrm{C}$ for the other rooms in the dwelling" [8].

The EP was studied in the Czech Republic too. The research conducted for the Ministry of Industry and Trade revealed that EP is primary caused by dwelling insufficient thermal isolating, the heating distribution system inadequate to the dwelling size and by the household total income. It implicates the household with one income only are in enhanced jeopardy of EP. Such households are single person households, senior households, uncompleted family households and families with one earning parent only [1].

The official Agency for Social Inclusion (Czech: Agentura pro sociální začleňování) researched that energy poverty in the Czech Republic is the result of several factors as following:

- household total income

- living costs (own flat, own flat with mortgage, release, cooperative flat)

- energy cost (the different energy carrier, the electric energy tariff, the illegal supply contract)

- energy efficiency (the building e. efficiency, the heating system, the household equipment)

- inhabitants' behavior (the health condition, the manners, the living style and priorities) [4].

Similarly as in the other EU countries the most vulnerable are the old people, especially single living. The other vulnerable groups are the families with absent father, the multi-children families, the 
unemployed people and health diseases people. The towns' inhabitants are in more jeopardy than village inhabitants [9].

As the EP is obviously undesirable, its root cases and the ways how to tackle EP were investigated. The most researchers think that appropriate solution is the dotation to cover the costs of measures enhancing the energy efficiency of the dwelling. Another suggested solution are the financial contributions to cover the energy expenditures are often mentioned. The both types of suggested donation should be funded by official social care institutes. This idea transforms the EP from individual private problem to the political topic because the dotation would be funded from the taxes of other citizens.

The Scottish Housing Act revealed in the year 2001 required the EM eradication till the November 2016 if it would be reasonably manageable. The deadline is over and the aim was not met [3].

The Energy Action Scotland claims "everybody has a right to live in safe, warm and dry house with affordable heating. For the millions of people living in the UK and suffering EP is this right declined" [2].

The Czech authors Pojar and Karásek mentioned that social flats and contributions for the poor organized by the government play significant role in the EM tackling however are useful just for energy expenditure reduction [5].

The Energy Observatory governed by the EU Commission revealed that almost 50 million people in the European Union are affected by energy poverty [7].

The Czech study about EP concludes that the households suffering EP cannot afford to invest into energy improving measures because the dominant portion of their incomes is expenditure for the heating. It is worthy to find any form of aid to ensure the acceptable living standard and contribute to cover their energy expenditure [5].

The main aim was to investigate the EP among the 288 clients of the Home Social Care Service (Czech: Domácí ošetřovatelská péče) in the Czech town Žd'ár nad Sázavou. This main aim divided into several goals. The first goal was to explore if the EM occurs among the target group members. The second goal was to express the severity of the EP if it would be found. The third goal was to find the cases of EP. The fourth goal was to suggest any possible solution how to tackle EP. The suggested solution should be affordable for the target group.

\section{Methodology}

The EP issue was investigated in Žd'ár nad Sázavou for the first time. This fact and the research aim implicated the used methods.

The first method was the literature review in order to obtain the basic overview about EP issue in the European states and about the EP studies former conducted in the Czech Republic.

The second method was the exploration and specifying of the target group. The target group was the old people living in the specific city district of Žd'ár nad Sázavou build in 50' for the employees of metallurgic factory Žd'as nearby. In this district live approximately 3000 people who moved in during $50^{\prime}$ and $60^{\prime}$ and now they are in post productive life period. All the apartments buildings in the whole district were built in same style and the flats are standardized in two types. The district was designed for the low-middle and middle class and this determination remains till current time. There are not extraordinary poor or rich people, the education, life style and other significant characteristics do not vary significantly. 
The target group members are old people without any knowledge about EP issue. This type of people was often misused by criminals who tried to intrude into their dwellings in order to steal any valuables. The criminals used to dissemble they are energy supplier employees and they came to check the electrometer or gas meter. After the liberalization of energy market many unfair sellers appeared who offered disadvantage energy contracts especially to the uninformed old people. Both types of criminal manners are very familiar among target group members and resulted to strong distrust to every unknown topic related to energy. This fact implicated that direct data gaining was impossible.

Because of reasons mentioned above the direct contact between target group and the researcher was impossible. The indirect way of data obtaining had to be find. The alternative way based on the experience of Home Social Care Service (HSCS) employees was used. The HSCS employees are in daily contact with target group representatives and are familiar with their living conditions.

According its status the HSCS should assist and provide medical and related social services at clients' homes in concordance with medical instructions and concerning the client needs. The typical services are injection application, blood sampling collection, bandage replacing, rehabilitate exercises [10]. The same client is repeatedly serviced by the unchanged HSCS employee in order to build the mutual trust. During the repeated visits the HSCS employee naturally learns the client's needs and is familiar with his/her household In case the low room temperature would occur repeatedly by many visits, it would be noticed by HSCS employee.

The third method was the explanation the EP issue to the HSCS employees. The term "energy poverty" was totally unfamiliar for them and the research aim seemed to be nonsense because did not fit to their approach to home social care. After the detailed explanation of the EP and the research aim the HSCS employees agreed to cooperate with the researcher. The HSCS willingness to cooperate was emphases that author is employed by Žd'ár nad Sázavou Magistrate and the Magistrate is the HSCS ruler. The author was perceived as more credible as unknown academic researcher.

Significant barrier breakers were the author's promises he will not offer any type of energy services to the HSCS clients and the research results will be published in the journal off the Žd'ár nad Sázavou citizens' attention.

The next barrier was the paragraph \#100 of the Act No. 108/2006 Col. About Social Services. According the Act the social workers cannot reveal the information about their clients. However the anonymized information can be provided for scientific purposes [12].

The EP was inspected in the group of Home Social Care Service's clients. The HSCS cares about 258 clients. The HSCS is organized in the city over the 25 years and is very experienced. The data about EP in the clients' households were gathered through the structured interview with HSCS employees.

The EP is basically technical issue however its research needs to use sociological instruments (structured interview or questionnaire) to obtain the data from the people suffered by the EP. The EP research combines the technical and sociological methods. The technically educated researcher usually has not enough experience to fulfill all the sociological requirements. Methodic mistakes can easy occur.

The technical characteristic of EP (e.g. room temperature, total income, expenditures for energy, dwelling isolation) can be exactly measured and quantified. However it is necessary to gather the input data from laic public. The gap between theoretically well prepared researcher and laic respondent easy could be source of misunderstanding with devastate bias on data collecting process.

The structured interview should be constructed regarding the laic point of view to the EP. The interview should cover many confidential topics as total income, incomplete family, dwelling stage, respondent's healthiness or illness, the behavior and living style, the mental capacity to recognize 
and solve the problem, the frequency and quality of contact with family members especially old people with their adult children and so on. All of these can be very sensitive for lot of old people especially when they feel any inconvenience in this matter and can be hardly answered correctly.

The HSCS by definition is focused on dependent and in need clients. Obviously the probability to be HSCS client increases with the person age. The most HSCS clients are the old people. The segments of young or healthy seniors (shortly after production period) were not proportionally represented because this type of people usually not became HSCS. The HSCS clients are not representative group of the all old people living in the given city district. The portion of dependent people among HSCS is higher than in the whole population.

The HSCS employees were interviewed in order to gain two types of information. Firstly the cause factors of the potential EP between HSCS clients were identified. Consequently the clients were divided into segments according their vulnerability by EP. Secondly the clients' numbers in each segment were estimated.

\section{Results}

The research was conducted during the winter 2018/2019 which was colder than previous years. The average temperature between the December 2018 and the February 2019 shows the Table 1. The used metering station is placed in the same city district as studied dwellings so the temperature values are relevant. The potential EP could be easy detected during this period.

Table 1: The average temperatures in Žd'ár nad Sázavou during the winter 2018/19.

\begin{tabular}{|l|c|c|}
\hline Month & $\begin{array}{l}\text { Average } \\
\text { temperature }\left[{ }^{\circ} \mathrm{C}\right]\end{array}$ & $\begin{array}{l}\text { Minimal } \\
\text { temperature }\left[{ }^{\circ} \mathrm{C}\right]\end{array}$ \\
\hline December 2018 & $-0,54$ & $-9,8$ \\
\hline January 2019 & $-3,25$ & $-17,7$ \\
\hline February 2019 & 0,31 & $-14,9$ \\
\hline March 2019 & 4,4 & $-4,4$ \\
\hline
\end{tabular}

\section{EP cause factors}

Based on the HSCS employees experience the following factors causing the EP were identified:

- Client's relative age

The HSCS employees noticed that the EP jeopardy depends on the clients' age. The clients' age should be viewed in the relation to the other HSCS clients. The young client means person in early senior period (usually male 65 years and female 61 years).

- Contact with the family

Many HSCS have insufficient contact with their family. The contact means not only the frequency of meetings with family members (children and grandchildren), however the client's cooperation with the other family members. The younger family members should be helpful and take care about senior dwelling in order to ensure his/her adequate wellbeing without EP. Unfortunately the cooperation absents very often because of client's unwillingness or help refusing. 
- Independence

Independence means the client's ability to care about himself and to cope daily duties without any assistance. The younger clients are more independent than older.

- Recommendation acceptability

The ability to accept any relevant advice or recommendation to improve client's manners or dwelling. Acceptance means that the client admits the problem and he/she efforts to solve it.

The EP cause factors defined by HSCS employees do not contain any technical parameters of the clients' flats. All the flats are in similar condition because were built by same technology in same period. The absence of technical parameters resulted from the fact that HSCS workers do not focus on technical issues of clients' flats during their services.

According the factors mentioned above the HSCS clients were divided into three segments which represent the most common types of clients. The border between the segments could not be exact. There are clients who do not fit to any segment. The segments' characteristics are summarized in Table 2.

Table 2: The resistance to EP among the Home Social Care Services clients.

\begin{tabular}{|c|l|l|l|l|l|l|}
\hline $\begin{array}{l}\text { Seg- } \\
\text { ment }\end{array}$ & $\begin{array}{l}\text { The portion } \\
\text { among HSCS } \\
\text { clients [\%] }\end{array}$ & $\begin{array}{l}\text { Relative } \\
\text { age }\end{array}$ & $\begin{array}{l}\text { Contact with } \\
\text { the family }\end{array}$ & Independence & $\begin{array}{l}\text { Recommen- } \\
\text { dation } \\
\text { acceptability }\end{array}$ & EP resistance \\
\hline A & $40-50$ & higher & $\begin{array}{l}\text { insufficient or } \\
\text { nonfunctional }\end{array}$ & dependent & almost zero & $\begin{array}{l}\text { inability to solve } \\
\text { inability } \\
\text { accept external } \\
\text { help }\end{array}$ \\
\hline B & 40 & middle & functional & $\begin{array}{l}\text { partially } \\
\text { dependent }\end{array}$ & average & $\begin{array}{l}\text { solving } \\
\text { family } \\
\text { cooperation }\end{array}$ \\
\hline C & 10 & $\begin{array}{l}\text { the } \\
\text { youngest }\end{array}$ & functional & independent & open mind & $\begin{array}{l}\text { solving } \\
\text { themselves; } \\
\text { independently } \\
\text { on family }\end{array}$ \\
\hline
\end{tabular}

\section{Clients in segment $A$}

The segment A contains the most EP vulnerable people. These people are the oldest from all the HSCS clients. Their contact with the family (in case they are not lonely) is often insufficient it means reduced on formal base and without any effective cooperation. These people usually cope the daily common duties as cooking, cleaning, shopping however they do it on minimal level. E.g. they are not able to clean the whole flat or repair some broken equipment. In addition the people of segment $A$ commonly use the oldest flat equipment with high energy demand.

These people are not open to any recommendations from the HSCS employees or family members. The typical reply is problem denying or refusing the suggested solution. The typical replies are "the mentioned defect is not important for me; I'm used to live in these condition for my whole life and I'm satisfied with it; the suggested solution it is not worthy for me, it will solve the flat new owner after me...". It is hard to recognize if they deny the problem because they do not recognize it or denying is a way how to avoid the effort to solve it. All the mentioned factors result to minimal lability to tackle EP. It is paradox the clients in segment A very often do not admit their EP and do not feel to 
be harmed by it. They think it is normal in their age and social status. The portion of segment $A$ is approximately $40-50 \%$ of HSCS clients.

\section{Clients in segment B}

The segment B members are middle age among the HSCS clients. These people usually stay in touch with their family and the family can assist them if necessary. They are partially dependent especially with task which need physical power or complexity. They are open to recommendations formulated by HSCS employees or family members. In case they recognize the problem (not only EP) they are able to solve it by themselves or by the family assistance. The significant difference to the segment $A$ is the perspective. The segment $B$ members think they will stay here longer and it is worthy to prepare for this period. These people can prevent or minimalize the EP by adequate measures. The segment B represents approx. $40 \%$ of the total amount of HSCS clients.

\section{Clients in segment $\mathrm{C}$}

The segment $\mathrm{C}$ members are the youngest and usually are not yet for long time in the rent period. These people are often cared by the HSCS because of injury and consequent rehabilitation exercises. They are active and responsible enough to case about their grandchildren if their parents (clients' children) need. This allows them to stay in functional touch with the family. Except of singular cases, these people are totally independent. They are able to perceive the problem or even anticipate it and adequately react. They are open mind to recommendations from HSCS employees. These people can recognize the jeopardy of EP and tackle it. The segment $C$ represents approx. $10 \%$ of the total amount of HSCS clients.

\section{The affordable low cost measures to tackle EP}

According the HSCS employees the basic measures for energy efficiency enhancing would be very beneficial for all the clients. The potential measures should be low cost because of these reasons:

- clients have not enough money for the high cost measure or do not want to invest to it

- recovery of investment of high cost measures is too long

- clients do not want to disturb their manners by any measures of large style

- the probability of low cost measure implementation is higher.

The low cost measures as the adequately long window curtains, the seal to the doors and windows, the thresholds adjustment could reduce the EP notably. The curtain into the entrance corridor as a barrier against warm air loses would be very useful as well. The replacement of the obsolete electrical equipment should be done in case of daily using. Typically the most used conventional bulbs in the household which daily operate for several hours should be replaced by the LED. The LED bulb have short return period of the investment. In other cases the recovery of investment can be too long. Another reason is the clients use old fashion equipment and it would be hard for many of them to learn how to manage the new one. 


\section{The EM jeopardy decreases with the client's age}

The segments A, B, C comparing shows that the ability to tackle EP decreases with the client's age. The older person the lower ability to admit the EP problem and lower motivation to solve it. The one of effective way how to tackle EP is the prevention. The prevention should be primary focused on segment $C$ which is mostly understandable and active for EP solving. The recommended solutions should reflect all the limits of target group to implement the measures.

\section{Conclusion and discussion}

The severity of EM among old people in Žd'ár nad Sázavou was investigated. The research topic is very sensitive and needs special soft approach to data gaining. The direct contact with the target group was not possible and the Home Social Case Service (HSCS) employees' experience was used instead of direct data gaining. The HSCS long time experience and the target group size of 258 clients allow to see the research as reliable. The research was influenced with subjective perception of interviewed HSCS employees. The HSCS clients are not representative group of all old people living in the studied city district. The portion of dependent people among HSCS is higher than in the whole population. The study results are influenced by this.

The identified factors enhancing the jeopardy of energy poverty were the relative age, the quality of contact with the family, the independence and the recommendation acceptability. The worse score in each factor the higher EP jeopardy.

The most effective instrument how to tackle EP in Žd'ár nad Sázavou seems the information campaign focused on the early seniors. These people are open mind and have enough power to prevent or at least minimalize the EP in their dwellings. The low cost measures to tackle EP should be offered. The probability to implement the low cost measure is higher among this target group.

The EP issue should be promoted among the social services workers as well. This topic needs to be accepted as serious thread for old people and social services should noticed it. According the Act No. 108/2006 Col. About Social Services the social workers should be trained annually at least 24 hours to obtain new professional skills. The EP issue should be part of this professional education training.

Note: the author organized the first lecture about energy poverty prevention in local senior club on in the November 2019. The audience found the lecture as useful and asked for the repetition in April 2020.

\section{References}

[1] Opatření proti energetické chudobě v ČR, Praha: SEVEn. 2016. Online [cited 1st April 2019] https://www.mpo-efekt.cz/upload/7799f3fd595eeee1fa66875530f33e8a/energetickachudoba-v12.pdf

[2] Energy Action Scotland (2017) Online [cited 1st April 2019] https://www.eas.org.uk/en/uk-fuelpoverty-monitor 50608/

[3] Housing (Scotland) Act 2001. Online [cited 2nd April 2019] http://www.legislation.gov.uk/ asp/2001/10/pdfs/asp 20010010 en.pdf 
[4] Energetická chudoba v Česku Workshop MPSV Pardubice, 30. listopadu 2017. Agentura pro sociální začleňování. Online [cited $4^{\text {th }}$ April 2019] https://www.mpsv.cz/files/ clanky/32390/3 Prezentace - Energeticka chudoba v CR.pdf

[5] Jiří Karásek, Jan Pojar Programme to reduce energy poverty in the Czech Republic Volume 115, April 2018, Pages 131-137 https://doi.org/10.1016/j.enpol.2017.12.045

[6] R. Day, G. Walker, N. Simcock. Conceptualising energy use and energy poverty using a capabilities Framework. Energy Policy, 93 (2016), pp. 255-264

[7] Energy Poverty Observatory - Addressing Energy Poverty in the European Union: State of Play and Action. online [cited 27th June 2019] Available at: https://www.energypoverty.eu/sites/ default/files/downloads/observatory-documents/19-06/paneureport2018_updated2019.pdf

[8] The Scottish Government. The Scottish Fuel Poverty Statement. Defining Fuel Poverty. [Online] [cited 27th April 2019.] http://www.gov.scot/Publications/2002/08/15258/9955.

[9] Schindler, Jan. Energetická chudoba - téma dneška. tzb-info.cz. [Online] 5th August 2014. [cited 27th April 2019.] http://energetika.tzb-info.cz/11557-energeticka-chudoba-tema-dneska-1.

[10] Sociální služby města Žd'ár nad Sázavou [cited 23th May 2019] https://www.socsluzbyzdar.cz/ sluzby/domaci-osetrovatelska-pece

[11] EnR Position Paper on Energy Poverty in the European Union - January 2019. Online [cited $2^{\text {nd }}$ May 2019] http://enr-network.org/wp-content/uploads/ENERGYPOVERTY-EnRPositionPaperEnergypoverty-Jan-2019.pdf

[12] Zákon č. 108/2006 Sb. O sociálních službách. Online [cited $4^{\text {th }}$ May 2019] https://www.zakonyprolidi.cz/cs/2006-108\#cast8

[13] Moore, R., Definitions of fuel poverty: Implications for policy. Energy Policy (2012), doi: 10.1016/ j.enpol.2012.01.057 